DOE/RL-93-69

UC. $-90^{\circ}$

\title{
Tri-Party Agreement Databases, Access \\ Mechanism and \\ Procedures
}

P. J. Brulotte

K. C. Christensen

Date Published

October 1993

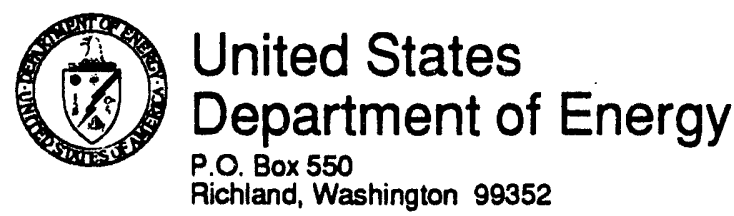

Approved for Public Release 
DOE/RL-93-69

\section{CONTENTS}

1.0 INTRODUCTION . . . . . . . . . . . . . . . . . 1

1.1 PURPOSE. STUCARE. . . . . . . . . . . . . . . . . . . . 1

1.2 DOCUMENT STRUCTURE . . . . . . . . . . . . . . . 1

2.0 SECURITY POINT OF CONTACT RESPONSIBILITIES . . . . . . . . . 3

3.0 HANFORD DATA NETWORKS ACCESS PROCESS . . . . . . . . . . . 5

3.1 NETWORK ACCESS METHODS ............. . . . 5

3.2 USER PREREQUISITE FOR ACQUIRING NETWORK ACCESS . . . . . . 5

3.2.1 Computer Resources Access Request Form . . . . . . . . 5

3.2 .2 ACE Request Form . . . . . . . . . . . . . 7

3.2 .3 Security Training Requirements.... . . . . . . . 9

3.3 DIAL UP ACCESS .................. . . . . 9

3.3.1 Dial Up Hanford Network Access Procedures . . . . . . . 9

3.3.2 Dial Up Hardware Requirements . . . . . . . . . . . 9

3.3 .3 Dial Up Constraints .............. . . . 9

3.4 DIRECT NETWORK ACCESS . . . . . . . . . . 10

3.4.1 Direct Network Access Procedures . . . . . . . . . . . 10

3.4.2 Direct Network Hardware Requirements . . . . . . . . 10

3.4.3 Direct Network Constraints ............ 10

4.0 TRI-PARTY AGREEMENT RELATED DATABASE ACCESS PROCESS . . . . . . . 11

4.1 ACCESS PASSWORDS . . . . . . . . . . . . . 11

4.2 DATABASE ACCESS PROCEDURES . . . . . . . . . . . . . . 11

5.0 DATABASE ABSTRACTS . . . . . . . . . . . . . . . 12

5.1 TRI-PARTY AGREEMENT RELATED DATABASES . . . . . . . . 12

5.2 OVERVIEW . . . . . . . . . . . . . . . 12

5.2.1 Computer Access Date . . . . . . . . . . . . . . . . . . 12

5.2.2 Computer Access Procedures . . . . . . . . . . . . 13

5.3 ABSTRACTS . . . . . . . . . . . . . . . . 13

Environmental Release Summary System (ERS) . . . . . . 14

Hanford Environmental Information System (HEIS) . . . . . . 15

Hanford Geographical Information System (HGIS) . . . . . . 16

Hanford Meteorological System (HMS) . . . . . . . . . . . . 17

Liquid Effluent Monitoring Information System (LEMIS) . . . . 18

Project and Data Management System (PDMS) . . . . . . . . 19

Sol id Waste Information and Tracking System (SWITS) . . . . 20

Surveillance Analysis Computer System (SACS) . . . . . . . 21

Tank Characterization Database (TCD) . . . . . . . . 22

Waste Information Data System (WIDS) . . . . . . . . 23

6.0 HANFORD LOCAL AREA NETWORK APPLICATIONS ACCESS PROCESS . . . . . . . 24

6.1 INTRODUCTION . . . . . . . . . . . . . . . . 24

6.2 HLAN APPLICATIONS . . . . . . . . . . . . . . . . . . . . 24

6.2 .1 cc:Mail .................... . . . 24

6.2 .2 cc:Mail Remote ................ 24

6.2.3 Hanford Pop-Up Phone Directory . . . . . . . . . . . . . 24

6.2 .4 Soft Reporting ................. 25 
DOE/RL-93-69

CONTENTS (cont)

7.0 ACCESS PROCESS GUIDELINE MATRIX . . . . . . . . . . . 26

8.0 REFERENCES . . . . . . . . . . . . . . . . 27 APPENDIX:

A. HANFORD DATABASE CONTACTS LIST . . . . . . . . . . . A-1

\section{LIST OF FIGURES}

1 Request for Timesharing Services and Logon ID (Form A-6000-304) . . 6

2 ACE User Data for Non DOE-RL Users (Form A-600-304A) . . . . . . . . 8 


\section{ABBREVIATIONS \& ACRONYMS}

$\begin{array}{ll}\text { CPPM } & \text { Computer Protection Program Manager } \\ \text { CTS } & \text { Customer Technical Service } \\ \text { DOE } & \text { U.S. Department of Energy } \\ \text { ECOlogy } & \text { Washington State Department of Ecology } \\ \text { EPA } & \text { U.S. Environmental Protection Agency } \\ \text { ERS } & \text { Environmental Release System } \\ \text { HEIS } & \text { Hanford Environmental Information System } \\ \text { HGIS } & \text { Hanford Geographical Information System } \\ \text { HLAN } & \text { Hanford Local Area Network } \\ \text { HMS } & \text { Hanford Meteorological System } \\ \text { LEMIS } & \text { Liquid Effluent Monitoring Information System } \\ \text { NPL } & \text { National Priorities List } \\ \text { PDMS } & \text { Project and Data Management System (PDMS) } \\ \text { RL } & \text { U.S. Department of Energy, Richland Operations office } \\ \text { RR/TPA } & \text { Manager of TPA Data and Records Management } \\ \text { SACS } & \text { Surveillance Analysis Computer System } \\ \text { SPC } & \text { Security Point of Contact } \\ \text { SR } & \text { Soft Reporting } \\ \text { SWITS } & \text { Solid Waste Information and Tracking System } \\ \text { TCD } & \text { Tank Characterization Database (TCD) } \\ \text { TPA } & \text { Hanford Federal Facility Agreement and Consent Order } \\ \text { WAM } & \text { Workstation Application Manager } \\ \text { WHC } & \text { Westinghouse Hanford Company } \\ \text { WIDS } & \text { Waste Information Data System (WIDS) }\end{array}$




\subsection{INTRODUCTION}

\subsection{PURPOSE}

This document contains the information required for the Washington State Department of Ecology (Ecology) and the U.S. Environmental Protection Agency (EPA) to access databases related to the Hanford Federal Facility Agreement and Consent Order [also known as the Tri-Party Agreement (TPA)] (Ecology et a1. 1992). It identifies the procedure required to obtain access to the Hanford computer networks and the TPA related databases. It addresses security requirements, access methods, database availability dates, database access procedures, and the minimum computer hardware and software configurations required to operate within the Hanford networks.

This document supersedes any previous agreements including the Administrative Agreement to Provide Computer Access to U.S. Environmental Protection Agency (EPA) (Wisness 1990a) and the Administrative Agreement to Provide Computer Access to Washington State Department of Ecology (Ecology) (Wisness 1990b), agreements that were signed by the U.S. Department of Energy (DOE), Richland Operations Office (RL) in June 1990. Access approval to EPA and Ecology is extended by $\mathrm{RL}$ to include all TPA related databases named in this document via the documented access method and date. Access to databases and systems not listed in this document will be granted as determined necessary and negotiated between Ecology, EPA, and RL.

Access to the TPA related databases and systems does not provide or imply any ownership on behalf of Ecology or EPA whether public or private in either the database or the system. Access to identified systems and databases does not include access to network/system administrative control information, network maps, etc.

\subsection{DOCUMENT STRUCTURE}

This document is organized into the following sections.

- Section 2.0 defines the responsibilities of the Ecology/EPA Security Point of Contact (SPC) relating to the use of Hanford computer resources.

- Section 3.0 identifies the requirements and process to access the Hanford computer networks. Accessing Hanford computer resources involves two distinct processes. First, access to a network is obtained. Then access to a specific database or system can be made (see Section 4.0). Network access is the same regardless of the database being accessed. The detail procedures for accessing the Hanford networks are documented in this section.

- Section 4.0 identifies the requirements and process to access specific applications or databases once the preliminary connection to a Hanford network is achieved. Access methods differ for each system because the procedures depend on the particular computer, 


\section{DOE/RL-93-69}

software, and hardware used. Only the manuals containing this information are identified in this document.

- Section 5.0 identifies the TPA related databases and summary information about each database. Key information includes the access availability date and means of access.

- Section 6.0 identifies the Hanford Local Area Network (HLAN) Applications available and summary information about each application.

- Section 7.0 is a matrix of all the actions required by a user to obtain access to Hanford computer resources.

- Appendix A identifies the individuals that can be contacted if there are questions about the data and/or databases access procedures. 


\subsection{SECURITY POINT OF CONTACT RESPONSIBILITIES}

Access to Hanford computer resources requires compliance to administrative and technical controls that protect DOE and Hanford contractor telecommunication, computer, and information resources. This document establishes the policies and procedures that permit RL to grant access to nonHanford entities and satisfy DOE and other national directives.

The first step in this administrative control process is the appointment, by Ecology and EPA, of an SPC who will implement a computer security program within their respective agencies that meets the requirements identified in this section. Failure to comply with security provisions pose a threat to the integrity of Hanford computer resources and may result in the cancellation of access authorization by RL or its contractors.

Before RL will authorize access to a Hanford database system an SPC and a)ternate (acceptable to RL) must be assigned by Ecology and EPA. The SPCs will be responsible for training the respective user community, aiding in investigating any suspected breaches of security by their user community, and coordinating the resolution of security problems with RL or the cognizant contractor as necessary.

The name, business address, and phone number of the SPCS and alternates must be provided to the Westinghouse Hanford Company (WHC) Manager of TPA Data and Records Management (RR/TPA). See Appendix A for the address and phone number. The SPC is responsible for ensuring compliance with the following requirements:

1. The SPCs and alternates will take annual training as identified by WHC Computer Protection Program Manager (CPPM).

2. The SPCS and alternates will ensure that prescribed security measures are followed. These include the following:

a. Implement the administrative, technical, physical, and personnel security measures employed to control access to Hanford databases described in the SPC training.

b. Provide computer security awareness training to personnel who manage, design, develop, operate, maintain, or use unclassified Hanford computer systems.

c. All personnel who access unclassified computer systems must have a working knowledge of unclassified computer security responsibilities (as stated in item $f$. below).

d. All actions constituting suspected or confirmed computer security incidents must be brought to the immediate attention of the RR/TPA manager. 
e. The following items will be included in all computer security awareness training given to any user authorized access to Hanford computing resources:

- Use only for AUTHORIZED job functions.

- Do not disclose Personal Identification Numbers or PASSWORDS.

- Do not risk introducing computer VIRUSES by using unauthorized software.

- Protect against SYSTEM MISUSE - log off when not in use.

- Notify the SPC of any unusual or SUSPICIOUS EVENTS, such as misuse or destruction of software or data.

f. Ensure all Ecology and EPA staff accessing Hanford computing resources have written approval for access by RL, the cognizant SPC, and WHC CPPM as documented in this document.

3. The SPC must inform the RR/TPA manager, within three working days of any staff member no longer needing access to Hanford computing resources. 
DOE/RL-93-69

\subsection{HANFORD DATA NETWORKS ACCESS PROCESS}

\subsection{NETWORK ACCESS METHODS}

EPA and Ecology can access Hanford computer resources with a direct network connection [this requires a physical connection to the HLAN or a dial up connection via a phone modem]. However, certain prerequisites are required to obtain access to these Hanford computer resources. Each prospective user must submit appropriate computer access request form(s), take computer security training, and have a computer that meets minimum hardware and software requirements.

\subsection{USER PREREQUISITE FOR ACQUIRING NETWORK ACCESS}

\subsubsection{Computer Resources Access Request Form}

Each Ecology and EPA prospective user wanting access to the Hanford network (direct or dial up) is required to complete a "Request for Timesharing Services and Logon ID" (Form A-6000-304) (Figure 1). Completion of this form requires the requestor's signature, acknowledging an understanding of the responsibilities and restrictions stated on the form, and the signature of cognizant SPC (in the supervisor name field). Send the form to the RR/TPA manager for distribution and processing.

- Complete the following information on the form:

Users Name -

Mailing Address -

Telephone Number -

Citizenship -
Full name (FML) of person applying for computer access

Work street, city, state, and zip

Work phone number (Include Area Code)

List country of citizenship

(NOTE: Computer access for non-U.S. citizens must be approved on a case-by-case basis by RL. Additional instructions will be provided, as required, to the SPCS by the WHC (PPM.)

DOE Clearance -

Circle NONE

Employee -

Name of agency requesting access (DO NOT ABBREVIATE) 


\subsubsection{Security Training Requirements}

After completion of the required form(s) specified in Sections 3.2.1 and 3.2.2, all users provided access to the Hanford network are required to take annual computer security training. Training materials will be provided to the SPCS by the WHC CPPM.

\subsection{DIAL UP ACCESS}

\subsubsection{Dial Up Hanford Network Access Procedures}

The procedures for accessing the network are provided with each Ace Card (see Section 3.2.2). The only information required in addition to that provided with the Ace Card is that the desired class of service is "NET1." See Section 4.2 for procedures to access a specific database.

\subsubsection{Dial Up Hardware Requirements}

The network can be accessed (dial up method) from a terminal with a telephone modem, a PC, or workstation with the use of a terminal emulation software package and a telephone modem.

- A terminal must be VT220 compatible.

- A PC-compatible computer system (80386 or better) is recommended because that is the only system type verified at the Hanford Site to work with the HLAN. A PC may use one of the following emulators (Kermit is recommended):

- MS-DOS Kermit Version 3.01 or later (also known by Kermit-MS and MS-Kermit)

- SmarTerm 240 Version 3.0b or later

- PC-TERM Version 3.2G or later

- VersaTerm Pro Version 2.10 or 2.20 for the Macintosh

- A workstation must use Xterm as the terminal emulator.

- The computer access system accepts data calls from 9600, 2400, 1200, and 300 bit-per-second modems only.

- The modem must be Hayes-compatible.

\subsubsection{Dial Up Constraints}

At present, remote access to the network is limited to 10 concurrent dial in users. There are four 9600 baud modems and six modems capable of 2400 , 1200 , or 300 baud access. 
Figure 2. ACE User Data for Non DOE-RL Users (Form A-600-304A).

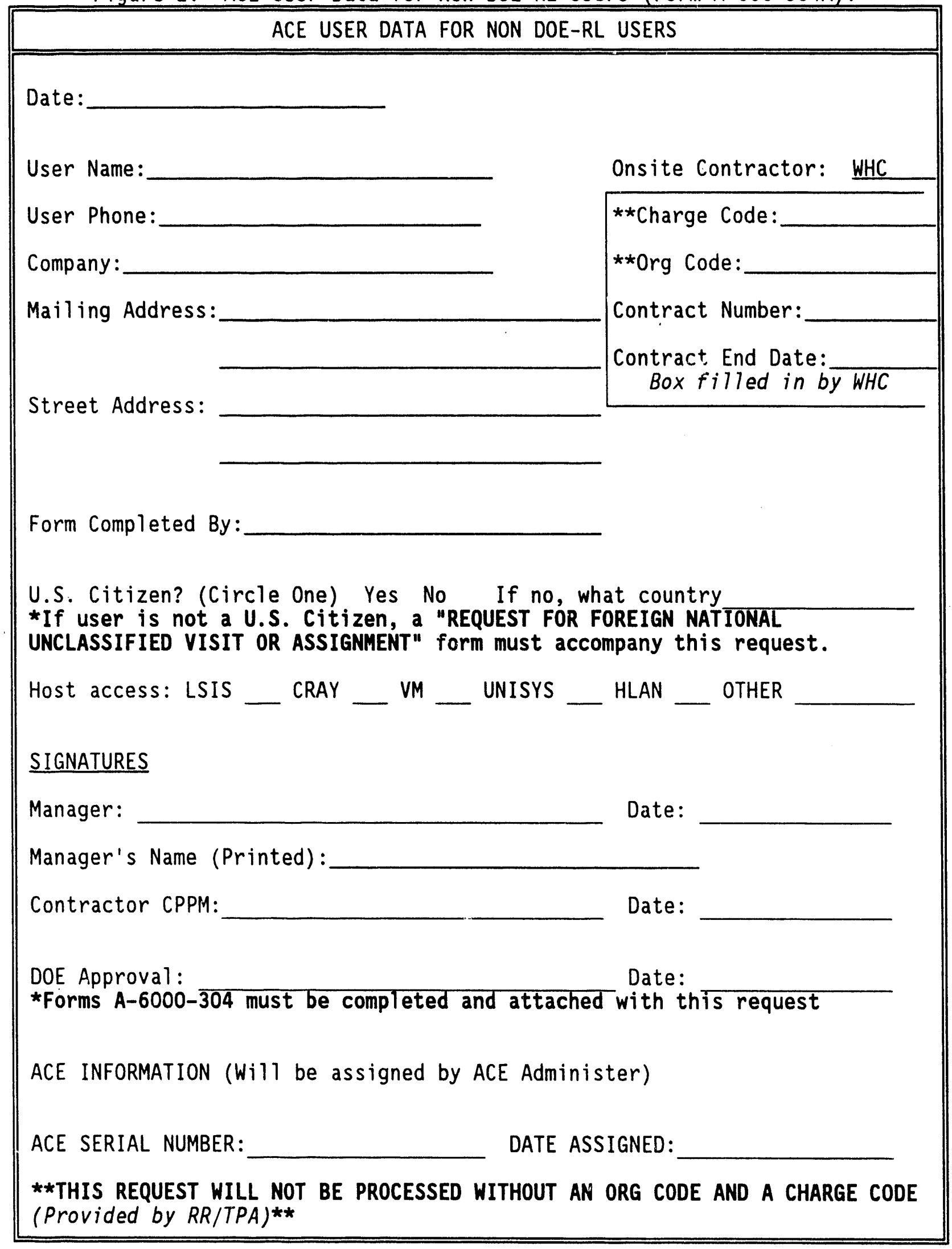



Resources Requested - List the name of the each database and/or systems to be accessed and all HLAN applications requested

(NOTE: See Section 5.0 for a list of systems and Section 6.0 for a description of HLAN applications.)

Purpose -

Specify reasons for requiring access to the identified computer resources.

Desired Start Date -

\subsubsection{ACE Request Form}

An additional form is required for dial up access. "ACE User Data for Non DOE-RL Users" (Form A-600-304A) (Figure 2) must be completed to obtain an Ace Card. An Ace card is used to generate passwords for dial up users when accessing Hanford computer resources. Send the form to the RR/TPA manager for distribution and processing.

- Complete the following information on the form:

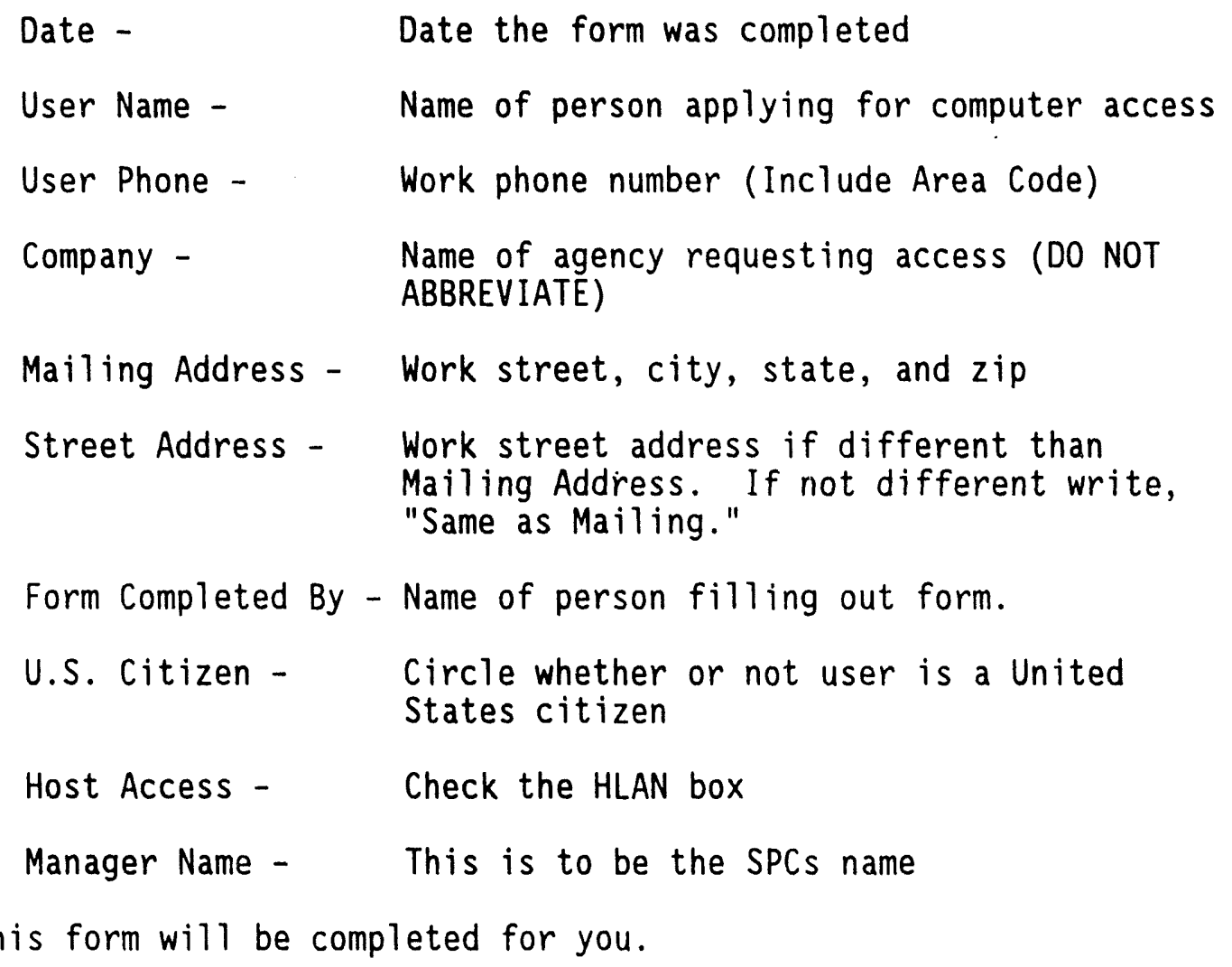

The rest of this form will be completed for you. 
Figure 1. Request for Timesharing Services and Logon ID (Form A-6000-304).

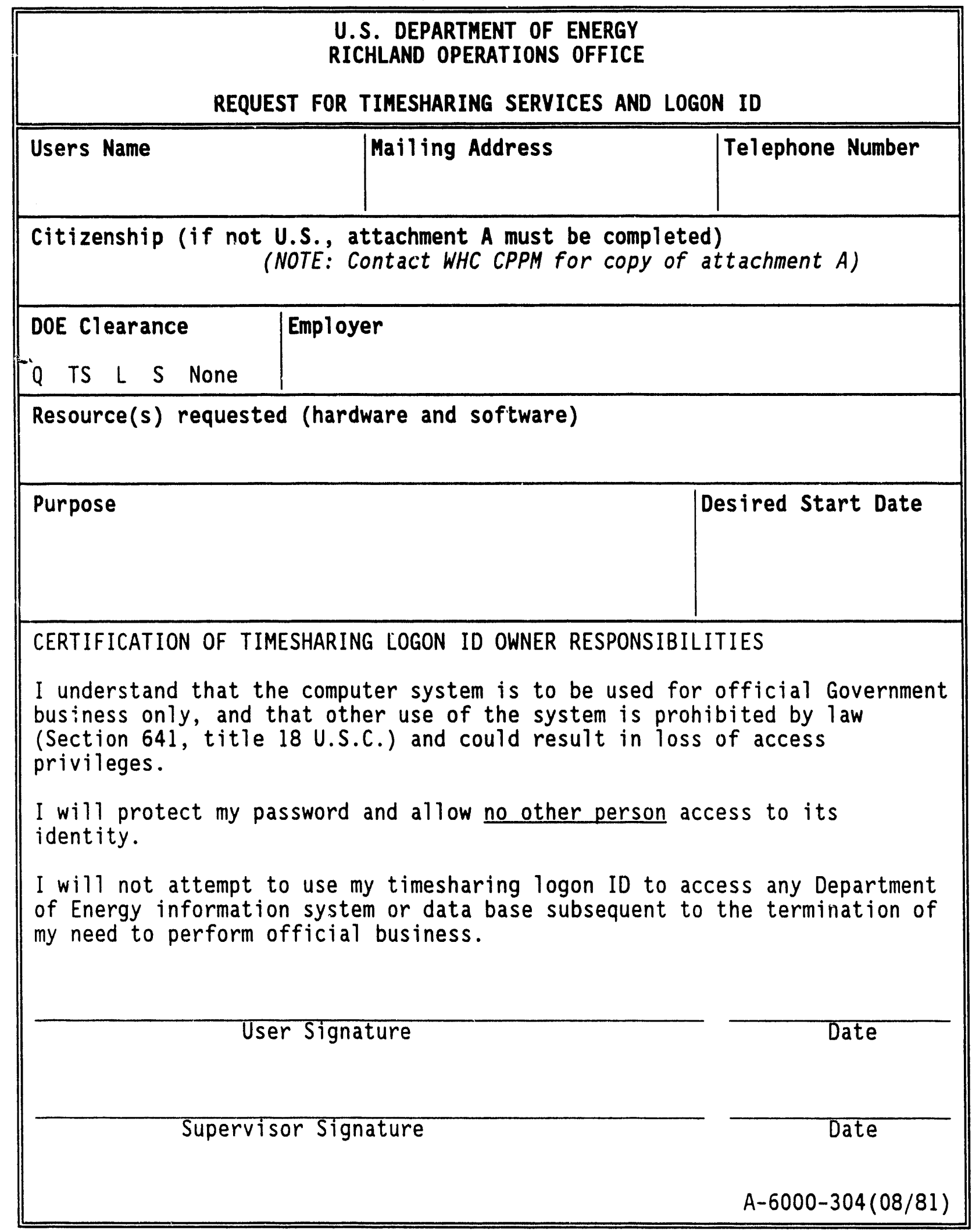


DOE/RL-93-69

\subsection{DIRECT NETWORK ACCESS}

\subsubsection{Direct Network Access Procedures}

When the physical connection to the HLAN is made by WHC Contact Customer Technical Service (CTS), a number of system files will be modified that will connect the user to HLAN. When booting up the PC, the user will be asked if network access is wanted. If yes, the users name and password is requested.

Once on the network, a Workstation Application Manager (WAM) Menu is displayed. The WAM program displays a menu on the PC screen along with date, time, and DOS prompt information. The names of supported applications are displayed on the screen and are selected with keyboard cursor keys, or alternately by typing the first letter of the name of the desired application. The WAM menu is tailored for the needs of each user. The WAM menu will provide the capability to access approved databases and network utilities. A copy of the WAM Users Manual can be obtained from CTS. See Section 3.2 for additional database access procedures.

\subsubsection{Direct Network Hardware Requirements}

A PC-compatible computer system (80386 or better) is recommended. Contact the CTS for a copy of the latest Micro Computer Standards Guide or for installation to the network.

\subsubsection{Direct Network Constraints}

Direct network access is dependent on having a physical connection to the network and a network board on the PC. Contact CTS for additional

information. 


\subsection{TRI-PARTY AGREEMENT RELATED DATABASE ACCESS PROCESS}

\subsection{ACCESS PASSWORDS}

Access to the Hanford network and to each TPA related database requires a password. The passwords will be provided to the EPA and Ecology staff by the cognizant CPPM(s).

\subsection{DATABASE ACCESS PROCEDURES}

Each database has its own access method. Specific access method procedures are documented in the associated system user manual identified in Section 5.3, Abstracts under the heading Computer Access Procedures. In addition to access methods, these manuals contain information on the content and capabilities of the system. These documents are the same documents used by the Hanford Site staff. Some features documented in the manuals, such as update and delete capabilities, will not be available to the Ecology and EPA staffs. 


\subsection{DATABASE ABSTRACTS}

\subsection{TRI-PARTY AGREEMENT RELATED DATABASES}

The following list identifies the Hanford TPA related databases.

- Environmental Release System (ERS)

- Hanford Environmental Information System (HEIS)

- Hanford Geographical Information System (HGIS)

- Hanford Meteorological System (HMS)

- Liquid Effluent Monitoring Information System (LEMIS)

- Project and Data Management System (PDMS) in HEIS

- Solid Waste Information and Tracking System (SWITS)

- Surveillance Analysis Computer System (SACS)

- Tank Characterization Database (TCD)

- Waste Information Data System (WIDS).

As documented in Section 5.3, "Abstracts," some of the databases' data will be accessed via HEIS, and a few databases will not have direct computer access. In the future, some databases may use other access systems and/or changes in technology may require changes in access methods and procedures. The SPCS will be provided, as required, updates to access procedures.

\subsection{OVERVIEW}

Once users have accessed the Hanford network, they will be able to access most of the databases 1 isted above, with the proper authorization (see Section 3.2). Information on how to access a specific database can be found in the computer access procedure documents identified in the Section 5.3, "Abstracts." Each abstract contains the following basic information about a database.

- Purpose

- Functions performed

- Scope of data

- Types of data

- Validation procedures used

- Database hardware

- Software

- Computer access date

- Computer access procedures.

Details on key items of information found in the abstracts are provided below. Also note that unless stated otherwise, the validation procedures referred to in the abstracts apply only to laboratory analytical data.

\subsubsection{Computer Access Date}

This is the date that Ecology and EPA will be able to access the database. User access on this date is contingent on submission of all required access forms. 
Access type, if other than direct computer access, is also noted under this heading. Data are provided via computer or hard copy reports. Computer access is either directly to a database via the Hanford network or a through copy of the data provided on tape or disk.

\subsubsection{Computer Access Procedures}

The manuals containing access information for specific databases are identified under this heading on each abstract. These are the same manuals used by the Hanford staff.

Manuals in the process of being cleared for release or being written are referred to in general terms. Once cleared, the manual number and name of the document will be provided to the SPCS. These documents will be available on or before the access date of the database.

\subsection{ABSTRACTS}

An abstract of each system 1 isted in Section 5.1 follows. 
SYSTEM NAME: Environmental Release Summary System (ERS)

PURPOSE:

The ERS reports estimated releases of radionuclides to the environment during specified time periods, from specified locations.

FUNCTIONS PERFORMED:

- Maintains database of radionuclides concentrations by specified location and time

- Calculates and reports releases of radionuclides releases

SCOPE OF DATA:

Samples from WHC facilities (100, 200/600, and 300/400 Areas).

TYPES OF DATA:

- Radiological analyses of effluent and environmental samples i.e.,

- $\quad$ Stack emissions

- Waste streams

- Ambient air samples

- Standing water samples

- Soil and vegetation samples

VALIDATION PROCEDURES USED:

WHC-IP-0697-1, Effluent Monitoring Program - 200600 Areas, (Manley 1992)

DATABASE HARDWARE:

PC

DATABASE SOFTWARE:

FORTRAN

COMPUTER ACCESS DATE:

Not planned. Access to data will be through hard copy reports.

Current Reports

- Annual Effluent Information System/Onsite Discharge Information System Report (This report includes information from all DOE sites.)

- Cumulative Decayed Inventories for Hanford Waste Disposal Sites

- On-demand report by sampling points, data type, time periods and location

- Air Emissions Report to EPA

- Environmental Release Report to RL

COMPUTER ACCESS PROCEDURES:

N/A (see Computer Access Date) 
PURPOSE:

HEIS provides computer-based access to quality-assessed Hanford Site environmental sample data.

FUNCTIONS PERFORMED:

- Sample number assignment

- Sample scheduling and tracking

- Data storage

- Database query and report generation

- Interface to HGIS

SCOPE OF DATA:

Analytical data and associated metadata

TYPES OF DATA:

- Groundwater

- Soils (surface and geologic)

- Biota

- Waste site

- Atmospheric

- Wells

- Water Levels

- Samples

- Locations

- Constituents

VALIDATION PROCEDURES USED:

WHC-SD-EN-SPP-002, Data Validation Procedures for Chemical Analysis, (Bechtold 1992)

WHC-SD-EN-SPP-001, Data Validation Procedures for Radiological Analysis, (Clark 1993)

DATABASE HARDWARE:

Sequent

DATABASE SOFTWARE:

Oracle

COMPUTER ACCESS DATE:

Currently available

COMPUTER ACCESS PROCEDURES:

WHC-EP-0372, Rev. 1, Hanford Environmental Information System - HEIS Users Manual, Rev 1 and Vol 1, (Schreck 1991) 
SYSTEM NAME: Hanford Geographical Information System (HGIS)

PURPOSE:

HGIS stores spatial data to support Hanford Site cleanup.

FUNCTIONS PERFORMED:

- Store data

- Display data

- Model data

- Prepare reports

\section{SCOPE OF DATA:}

- National Priorities List (NPL) data for the Hanford Site

- Sitewide Data - Hanford Site and 50 mile radius

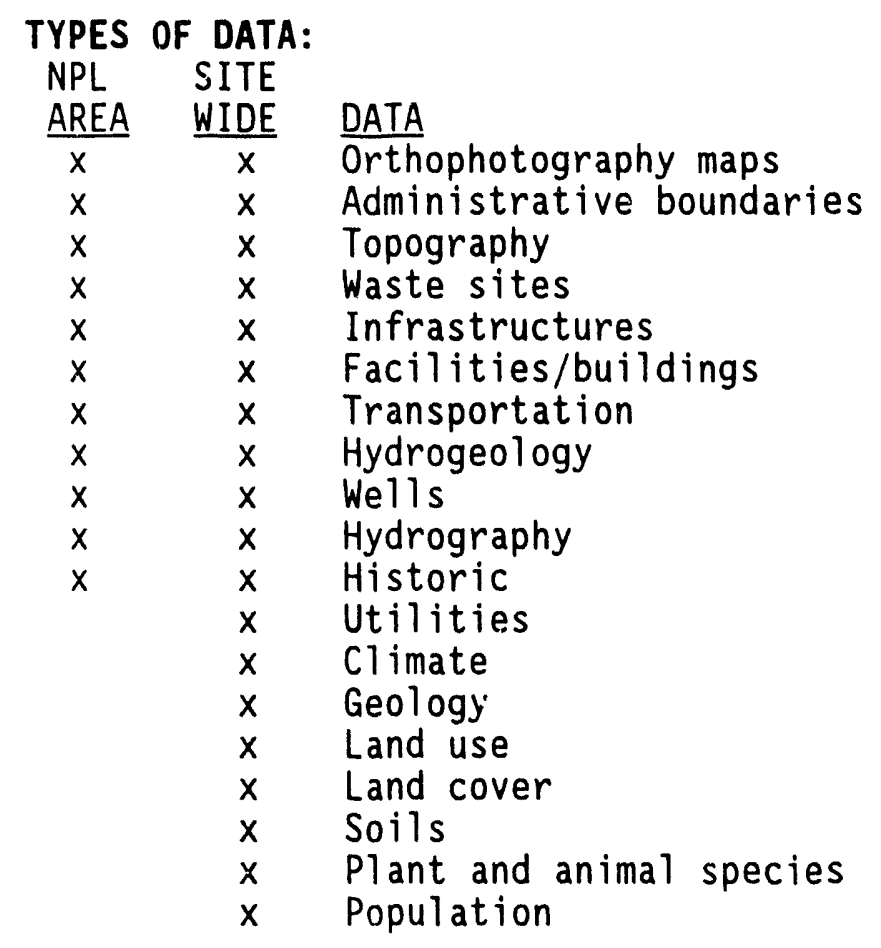

VALIDATION PROCEDURES USED:

$\mathrm{N} / \mathrm{A}$

DATABASE HARDWARE:

SUN

DATABASE SOFTWARE:

Arc-Info

COMPUTER ACCESS DATE:

Not planned. Volume of data precludes HLAN access. Data is shared currently via magnetic tape.

COMPUTER ACCESS PROCEDURES:

HGIS Technical Manual (under development) 
SYSTEM NAME: Hanford Meteorological System (HMS)

PURPOSE:

HMS provides 24-hour-a-day meteorological and climatological support for emergency response, weather forecasting, climatological data, and special meteorological requests to RL and Hanford Site contractors.

FUNCTIONS PERFORMED:

- Surface observations

- Weather forecasting

- Data collection

- Data archival

- Data summarization

SCOPE OF DATA:

Data is collected every 15 minutes from 28 locations around the Hanford Site and surrounding area.

TYPES OF DATA:

- Wind speed and direction

- Temperature

- Precipitation

- Pressure

- Sky cover

- Obstructions to visibility

- Weather (rain, snow)

- Relative humidity

VALIDATION PROCEDURES USED:

N/A

DATABASE HARDWARE:

IBM RISC/System 6000

DATABASE SOFTWARE:

C, FORTRAN, UNIX, Windows

COMPUTER ACCESS DATE:

Not planned. Access to data will be through hard copy reports.

COMPUTER ACCESS PROCEDURES:

N/A (see Computer Access Date) 
PURPOSE:

LEMIS schedules, documents, and records sample collection activity and sample results obtained from each of the effluent streams that discharge to the soil column.

FUNCTIONS PERFORMED:

- Schedule sample events

- Prepare sample authorization forms

- Store analytical results

SCOPE OF DATA:

- All liquid effluent streams on the Hanford Site

TYPES OF DATA:

- Identification and location of waste streams and sample collection points

- Identification, frequency, and location of samples

- Laboratory results of sample collection analysis from each waste stream by location and date

- Analytical methods

- Field sample collection information

VALIDATION PROCEDURES USED:

WHC-CM-5-3, Sample Management Administration, Sections 2.0 and 2.4, (WHC 1992b)

DATABASE HARDWARE:

SUN

DATABASE SOFTWARE:

Oracle

COMPUTER ACCESS DATE:

September 30, 1993

COMPUTER ACCESS PROCEDURES:

LEMIS Users Guide (under development) 
DOE/RL-93-69

SYSTEM NAME: Project and Data Management System (PDMS)

PURPOSE:

PDMS supports surface environmental surveillance activities for the Hanford Site.

FUNCTIONS PERFORMED:

- Sample scheduling

- Sample tracking

- Storage of analytical results

- Support of data analysis activities (graphics, statistics, data reporting, quality assurance)

SCOPE OF DATA:

The Hanford Site and surrounding area, except for the various facilities on site.

\section{TYPES OF DATA:}

- Air

- Water

- Foodstuffs

- Soil

- Vegetation

- Sediment

- Wildlife

- External radiation surveys and thermoluminescent dosimeter surveys

- River flow rate, and temperature

VALIDATION PROCEDURES USED:

$N / A$

DATABASE HARDWARE:

Sequent

DATABASE SOFTWARE:

Oracle

COMPUTER ACCESS DATE:

February 1, 1994 via HEIS (PDMS system is being replaced by HEIS)

COMPUTER ACCESS PROCEDURES:

WHC-EP-0372, Rev. 1, Hanford Environmental Information System - HEIS

Users Manual, Rev 1 and Vol 1, (Schreck 1991) 
PURPOSE:

SWITS supports the solid waste management program in managing radioactive mixed and hazardous solid waste treatment and storage and eventual

disposition onsite or offsite.

FUNCTIONS PERFORMED:

- Provide real-time inventories for onsite treatment, storage, and disposal facilities

- Track waste shipments onsite and offsite

- Provide regulatory reports for federal and state agencies

- Provide information in support of remediation activities

SCOPE OF DATA:

Container-specific radioactive and nonradioactive solid waste data from onsite and offsite facilities from 1944 to present. SWITS information includes waste characterization, shipment, location history, and final disposition.

TYPES OF DATA:

- Radionuclides, quantity

- Chemical and physical components

- Storage location

- Shipment and manifest data

- $\quad E P A$ dangerous waste numbers

VALIDATION PROCEDURES USED:

N/A

DATABASE HARDWARE:

SUN

DATABASE SOFTWARE:

Oracle

COMPUTER ACCESS DATE:

April 1, 1994

COMPUTER ACCESS PROCEDURES:

SWITS Users Manual (under development) 
DOE/RL-93-69

SYSTEM NAME: Surveillance Analysis Computer System (SACS)

PURPOSE:

SACS is the central, long-term data storage system (database) for WHC tank farm surveillance data. SACS has the flexibility for future additions of data types.

FUNCTIONS PERFORMED:

- Instantaneous analysis of

Current

- Surface liquid levels

- Temperature data

- Vapor space dome pressure

Planned

- Vapor space gas composition

- Liquid observation well data

- Drywe1l/lateral data

SCOPE OF DATA:

Surveillance data of underground nuclear waste tanks that are located in the Hanford Site's 200 areas.

TYPES OF DATA:

Measurements from surface level and temperature sensors

VALIDATION PROCEDURES USED:

$\mathrm{N} / \mathrm{A}$

DATABASE HARDWARE:

SUN

DATABASE SOFTWARE:

Oracle

COMPUTER ACCESS DATE:

May 31, 1994

COMPUTER ACCESS PROCEDURES:

SACS Users Manual (in development) 
SYSTEM NAME: Tank Characterization Database (TCD)

PURPOSE:

TCD was developed initially to support a leave/retrieve decision for tank waste. Under revised TPA Milestone 10, TCD also supports final disposal

decisions for tank waste and performs characterization requirements.

FUNCTIONS PERFORMED:

Maintain tank waste content data.

SCOPE OF DATA:

TCD Includes physical properties and all laboratory analys is results for single-shell tank core, double-shell tank core, double-shell tank supernatant grout candidate tanks, and grout feed tanks.

TYPES OF DATA:

- Core sample analytical results including

- Qualifiers

- Flags

- $\quad$ Spike recovery

- Rheology

- Inventory of tank contents

VALIDATION PROCEDURES USED:

WHC-CM-5-3, Sample Management Administration, Sections 2.0 and 2.4, (WHC 1992b)

DATABASE HARDWARE:

Sequent

DATABASE SOFTWARE:

Oracle

COMPUTER ACCESS DATE:

January 30,1994

COMPUTER ACCESS PROCEDURES:

WHC-EP-0372, Rev. 1, Hanford Environmental Information System - HEIS

Users Manual, Rev 1 and Vol 1, (Schreck 1991)

TCD Users Manual (under development) 
DOE/RL-93-69

SYSTEM NAME: Waste Information Data System (WIDS)

PURPOSE:

WIDS provides a traceable source of historical, radiological

surveillance, hazardous chenical, and environmental characterization data for all waste sites at the Hanford Site. WIDS provides valid, reliable, and traceable waste site data that is essential to long-range waste management and environmental planning.

FUNCTIONS PERFORMED:

The official source of Hanford Waste Site information. The system gathers, stores, and disseminates Waste Site information. WIDS prepares reports and provides historical data.

SCOPE OF DATA:

Contains information on all Hanford waste sites from start up through current data, including items such as septic systems and solid waste management units (EPA defined).

TYPES OF DATA:

- Waste Site

- Name and location

- Physical description

- Waste description including inventories if available

VALIDATION PROCEDURES USED:

$N / A$

DATABASE HARDWARE:

PC

DATABASE SOFTNARE:

PARADOX

COMPUTER ACCESS DATE:

Currently available through shared copies of the database.

COMPUTER ACCESS PROCEDURES:

A formal document does not exist. Instructions have been provided to Ecology and EPA SPCs. 
$\mathrm{DOE} / \mathrm{RL}-93-69$

\subsection{HANFORD LOCAL AREA NETWORK APPLICATIONS ACCESS PROCESS}

\subsection{INTRODUCTION}

This section identifies HLAN applications available for direct connect network users. One exception, cc:Mail Remote, is available to dial up network access users. Request to use any of these applications must be approved by RL via the "Request for Timesharing Services and Logon Id" form (see

Section 3.2.1). The applications currently available to Ecology and EPA are:

- cc:Mail

- cc:Mair Remote

- Hanford Pop-Up Phone Directory - for direct connect network users

- Soft Reporting

Contact the CTS manager for assistance in using the applications or to obtain the documentation listed below.

\subsection{HLAN APPLICATIONS}

\subsection{1 cc:Mail}

CC:Mail is an electronic mail program. Virtually anything created on a $P C$ can be sent to another PC on the Hanford Network. Text, graphics, and entire DOS files can be sent or received in the same message.

Documentation is available by calling CTS and requesting a Cc:Mail Users Manual and/or cc:Mail Learning Guide.

\subsection{2 cc:Mail Remote}

cc:Mail Remote has the same functionality as cc:Mail. cc:Mail Remote allows remote standalone PCs to send and receive mail from the HLAN.

The use of cc:Mail Remote requires a copy of the cc:Mail Remote software and a modem. Cc:Mail Remote software can be purchased from software vendors. The minimum requirement for a modem is a Hayes compatible modem 2400 baud or greater. The recommended modem is a U.S. Robotics Courier V32 high speed compatible modem 9600 baud or greater. utility.

The CTS wili provide a set of instructions to the user requesting this

\subsubsection{Hanford Pop-Up Phone Directory}

The Hanford Pop-Up Phone Directory system is comprised of two directories. The first is an alphabetic directory of RL, RL Prime contractor, subcontractor, and other Hanford-related personnel and associated information. 
The second is an alphabetic directory of services available at Hanford, otherwise known as the 'Yellow Pages.'

Documentation is available by calling CTS and requesting the Hanford PopUp Phone Directory manual.

\subsubsection{Soft Reporting}

Soft Reporting (SR) is a network based report viewing application. It allows users to view, download, and print stored reports and eliminates the need for printing multiple copies for distribution.

Soft Reporting reports to be viewed by Ecology and EPA are currently located the TPAl file server.

For complete instructions on how to use SR, the SR User's Guide may be printed from within SR. 
$\mathrm{DOE} / \mathrm{RL}-93-69$

\subsection{ACCESS PROCESS GUIDELINE MATRIX}

\begin{tabular}{|c|c|c|c|}
\hline ACTION REQUIRED & BY & $\begin{array}{l}\text { SOURCE OF } \\
\text { INSTRUCTIONS } \\
\text { (SECTION) } \\
\end{array}$ & $\begin{array}{l}\text { ADDITIONAL } \\
\text { INFORMATION } \\
\text { (SECTION) } \\
\end{array}$ \\
\hline $\begin{array}{l}\text { Complete Computer Access } \\
\text { Request Form (CAR) }\end{array}$ & $\begin{array}{l}\text { Person } \\
\text { requesting } \\
\text { FIRST TIME } \\
\text { access to any } \\
\text { Hanford } \\
\text { computer } \\
\text { resource } \\
\\
\text { requesting } \\
\text { NEW/ADDITIONAL } \\
\text { computer } \\
\text { resources. }\end{array}$ & 3.3 .1 & $5.3,6.0$ \\
\hline Complete ACE Request Form & $\begin{array}{l}\text { Person using } \\
\text { dial up network } \\
\text { access method }\end{array}$ & 3.1 .2 & 3.3 \\
\hline $\begin{array}{l}\text { Sign CAR and ACE forms \& send } \\
\text { to the Manager TPA Data and } \\
\text { Records Management (See } \\
\text { Appendix A. for address and } \\
\text { phone number. }\end{array}$ & SPC & $\begin{array}{l}3.3 .1 \\
3.1 .2,2.0\end{array}$ & \\
\hline $\begin{array}{l}\text { Complete computer security } \\
\text { training }\end{array}$ & $\begin{array}{l}\text { Person } \\
\text { requesting } \\
\text { access }\end{array}$ & 3.2 .3 & 2.0 \\
\hline $\begin{array}{l}\text { Follow } A C E \text { receipt } \\
\text { instructions }\end{array}$ & $\begin{array}{l}\text { Person } \\
\text { receiving ACE } \\
\text { card }\end{array}$ & 3.1 .2 & \\
\hline $\begin{array}{l}\text { Check computer hardware } \\
\text { requirements }\end{array}$ & $\begin{array}{l}\text { Person } \\
\text { requesting } \\
\text { access }\end{array}$ & $\begin{array}{l}3.3 .2 \\
3.4 .3\end{array}$ & \\
\hline $\begin{array}{l}\text { Access Hanford computer } \\
\text { resources }\end{array}$ & $\begin{array}{l}\text { Person } \\
\text { accessing data }\end{array}$ & $\begin{array}{l}3.3 .1, \\
3.4 .1,4.2 \\
\end{array}$ & \\
\hline
\end{tabular}




\subsection{REFERENCES}

Bechtold, R. A., 1992, Data Validation Procedures for Chemical Arlalysis, WHC-SD-EN-SPP-002, Westinghouse Hanford Company, Richland, Washington.

Clark, D. E., 1993, Data Validation Procedures for Radiological Analysis, WHC-SD-EN-SPP-001 Rev. 1, Westinghouse Hanford Company, Richland, Washington.

DOE/RL, 1992, Policy for Granting Access for Non-Hanford Entities to RL Automated Information Resources, RLIP-1360.3a, U.S. Department of Energy, Richland Field Office, Richland, Washington.

Ecology, EPA, and DOE, 1992, Hanford Federal Facility Agreement and Consent Order, 2 vols., as amended, Washington State Department of Ecology, U.S. Environmental Protection Agency, and U.S. Department of Energy, 0lympia, Washington.

Manley, C. L., 1992, Effluent Monitoring Program - 200600 Areas, WHC-IP-0697-1, Westinghouse Hanford Company, Richland, Washington.

Schreck, R.I., 1991, Hanford Environmental Information System - HEIS Users Manual, Rev 1 and Vol 1, WHC-EP-0372 Rev 1, Westinghouse Hanford Company, Richland, Washington.

WHC, 1992b, Sample Management Administration, WHC-CM-5-3, Westinghouse Hanford Company, Richland, Washington.

Wisness, S.H., 1990a, Administrative Agreement to Provide Computer Access to U.S. Environmental Protection Agency (EPA), (letter 9002523 to P.T. Day, June 28), U.S. Department of Energy - Richland Field Office, Richland, Washington.

Wisness, S.H., 1990b, Administrative Agreement to Provide Computer Access to Washington State Department of Ecology (Ecology), (letter 9002523 to T. L. Nord, June 23), U.S. Department of Energy - Richland Field Office, Richland, Washington. 


\section{TRADEMARKS}

Arc-Info is a trademark of Environmental Systems Research Institute, Inc.

$C$ is a trademark of Bell Laboratories.

cc:Mail is a trademark of cc:Mail, Inc.

Hayes is a trademark of Hayes Microcomputer Products, Inc.

IBM RISC/System 6000 is a trademark of International Business Machines Corporation.

Kermit is a trademark of Columbia University Center.

Macintosh is a trademark of Apple Computer Corporation.

Oracle is a trademark of Oracle corporation.

Paradox is a trademark of Borland International, Inc.

PC-TERM is a trademark of Crystal Point, Inc.

Sequent is a trademark of Sequent Computer Systems, Inc.

SmarTerm 240 is a trademark of Persoft Inc.

SUN is a trademark of Sun Microsystems.

UNIX is a trademark of AT\&T in the U.S.A. and other countries

U.S. Robotics is a trademark of U.S. Robotics, Inc.

VersaTerm Pro is a trademark of Abelbeck Software

Windows is a trademark of Microsoft Corporation.

80386 is a trademark of Intel Corporation. 
$\mathrm{DOE} / \mathrm{RL}-93-69$

\section{ATTACHMENT A}

\section{HANFORD DATABASE CONTACTS LIST}

PRIMARY CONTACT - RR/TPA Manager

Westinghouse Hanford Company

Manager TPA Data and Records Management

Frank Calapristi

MSIN B2-35

P.0. Box 1970, Richland, WA 99352

Phone (509) 376-6693

\section{TECHNICAL DATABASE CONTACTS}

Environmental Release System Larry P. Diediker, Manager Effluent Emission Monitor

Phone (509) 376-1716

Hanford Environmental Information System

Hanford Geographical Information System

Waste Information Data System

Richard D. Fox, Manager Environmental Data Management

Phone (509) 376-3261

Hanford Meteorological System (HMS)

Danna J. Hoitink, Project Manager Meteorological and Climatological

Services

Phone (509) 376-8864

Liquid Effluent Monitoring Information System

Dwayne R. Speer, Manager Interim Streams Program

Phone (509) 373-3110

Project and Data Management System

Roger K. Woodruff, Program Manager Surface Environmental Project

Phone (509) 376-7887

Solid Waste Information and Tracking System

Ken L. Hladek, Manager Solid Waste Systems Engineering

Phone (509) 376-5471

Surveillance Analysis Computer System

Richard K. Welty, Manager Tank Surveillance Technology

Phone (509) 373-1008

Tank Characterization Database

Donald B. Engleman, Manager Characterization Program

Phone (509) 373-3452

\section{CUSTOMER TECHNICAL SERVICES (CTS)}

Jorge F. (Frank) Armijo, Manager 700 Area EUC/CTS

Phone (509) 376-5391 


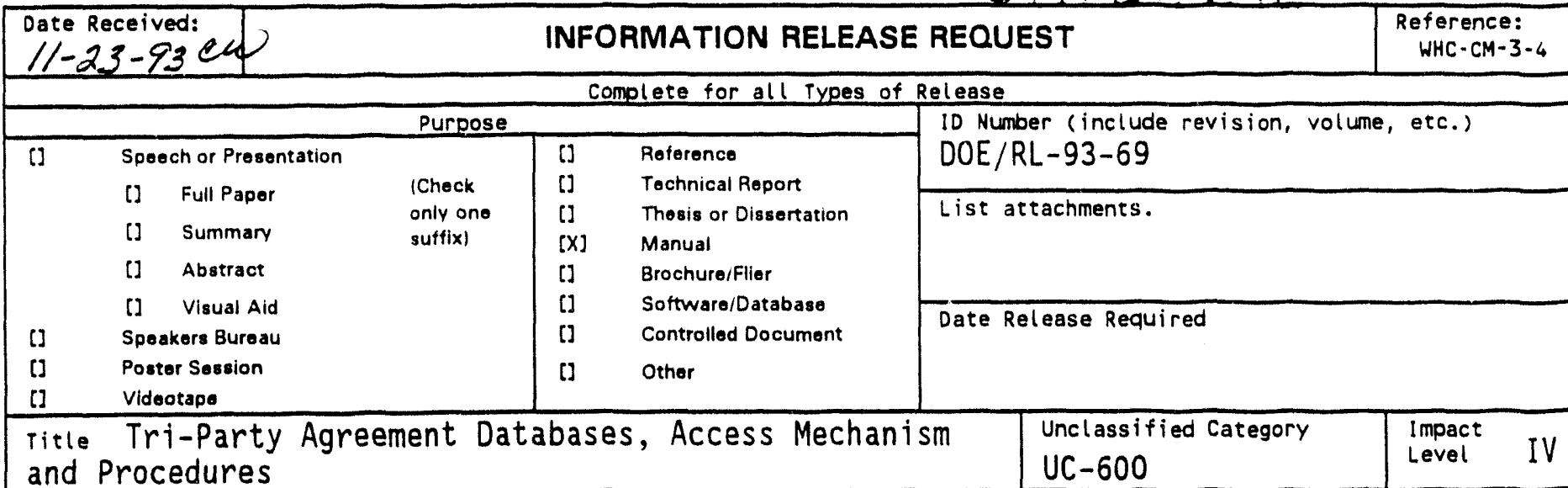

Now or novel (patentable) subjoct matter? $[X]$ No [] Yes

If "Yos", has disclosure been submitted by WHC or other company?

[] No [] Yes Disclosure No(s).

Copyrights? $[X]$ No [] Yos

If "Yos", has writton permission been granted?

[] No [] Yos (Attach Pormission)

Information recoived from others in confidence, such as proprietary data. trade secrets, and/or inventions?

$[\mathrm{X}]$ No [] Yos (ldentify)

Trademarks?

[] No $[\mathrm{X}]$ Yos (Identify)

\begin{tabular}{|l|l|l}
\hline Title of Conference or Meeting & Group or Society Sponsoring
\end{tabular}

\begin{tabular}{|c|c|c|c|c|}
\hline Date(s) of Conference or Meeting & City/State & $\begin{array}{l}\text { Will proceedings be published? } \\
\text { Will material be handed out? }\end{array}$ & $\begin{array}{l}\text { Yes } \\
\text { Yes }\end{array}$ & $\begin{array}{l}\text { No } \\
\text { No }\end{array}$ \\
\hline
\end{tabular}

Title of Journal

CHECKLIST FOR SIGNATORIES

Review Required per WHC-CM-3-4 Yes No Reviewer - Signature Indicates Approval

Classification/Unclassified Controlled Name (printed)

signature

Date

Nuclear Information

[] [ [ [

Patent - General Counsel

$\triangle$ [] SivneeGLIU

Legal - General Counsel

Applied Technology/Export Controlled

Information or International Program

[] BD Williamson

feclenden

$11 / 12 / 23$

WHC Program/Project

Communications

[ ] [4

[] [4]

[] []

RL. Program/Project

$[1]$

[] S. Wisness Prtileen DoE Reviete not requinsedell

Publication Services

[4

Other Program/Project

[]

[] KN Liikala Lim hïkula $11 / 23 / 98$ 11-28.95

Information conforms to all applicable requirements. The above information is certified to be correct.

\begin{tabular}{lll}
\hline References Available to Intended Audience & $\underline{\text { Yes }}$ & No \\
Transmit to DOE.HO/Office of Scientific & {$[X]$} & {[]}
\end{tabular}

and Technical Information

Author/Requestor (Printed/Signature)

[ ] $[x]$ Date

P. J. Brulotte

Intended Audience

[] Internal [] sponsor [X] External

Responsiblè Manager (Priofed/signature) Date

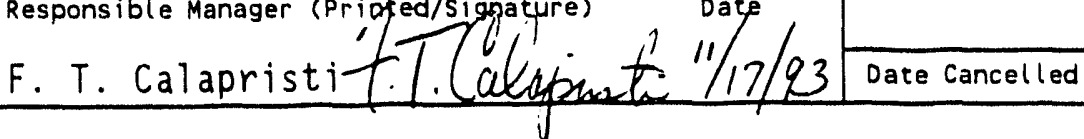
INFORMATION RELEASE ADMINISTRATION APPROVAL STAMP

Stamp is required before release. Release is contingent upon resolution of mandatory comments.

새

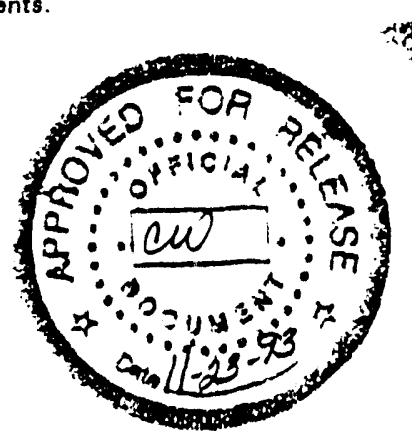


DOE/RL-93-69

\section{DISTRIBUTION}

Number of copies

ONSITE

24

U.S. Department of Energy.

Richland Operations office

S. H. Wisness A5-15

Pacific Northwest Laboratory

P. J. Cowley K7-22

D. J. Hoitink K6-55

R. K. Woodruff K6-61

Westinghouse Hanford Company

J. F. Armijo A3-50

P. J. Brulotte B4-54

F. T. Calapristi B2-35

L. P. Diediker Tl-30

D. B. Ennzelman R2-18

R. D. Fox H6-07

K. L. Hladek N3-13

K. M. Liikala A2-24

G. J. Mishko R2-12

D. R. Speer R3-46

C. F. Wagner A2-90

R. K. Welty R1-80

DOE-RL Reading Room Al-65

Document Processing and

Distribution (2) L8-15

Central Files L8-04

Document Clearance Administration (3) A3-36

PNL Technical Files

$\mathrm{K} 1-11$ 

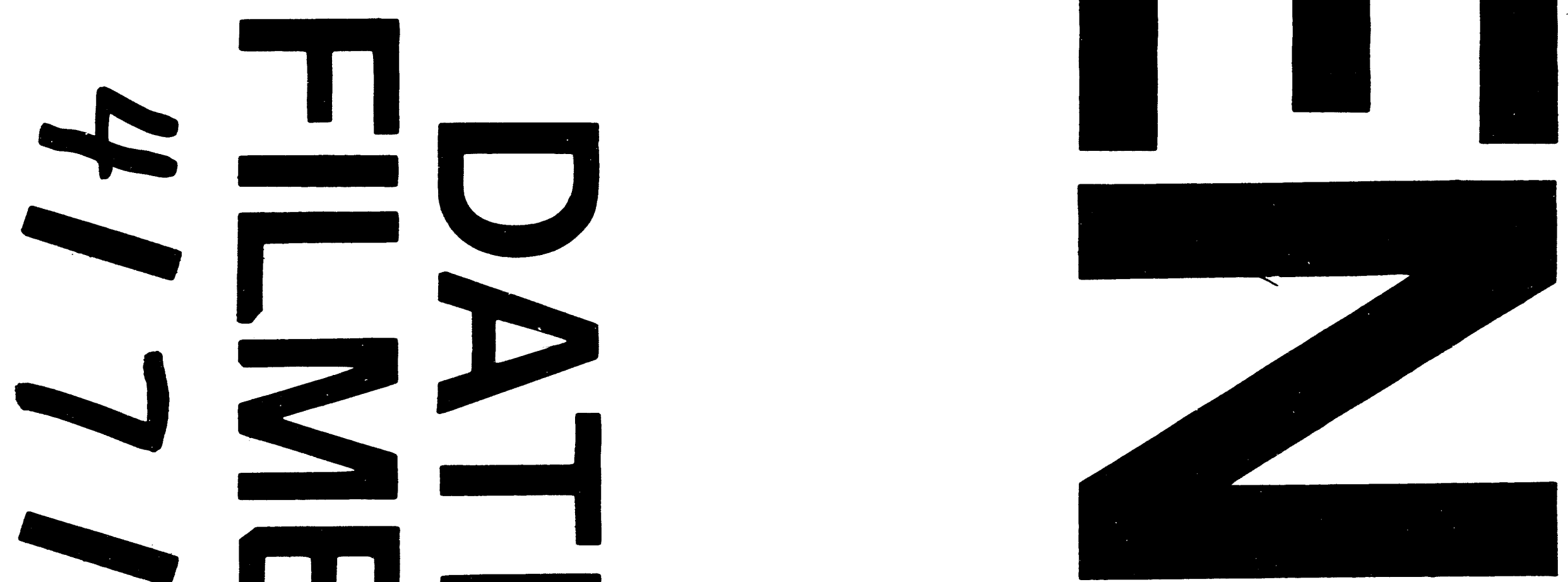

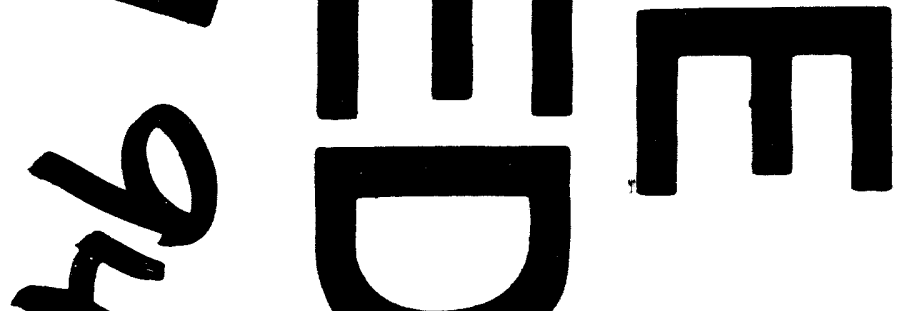

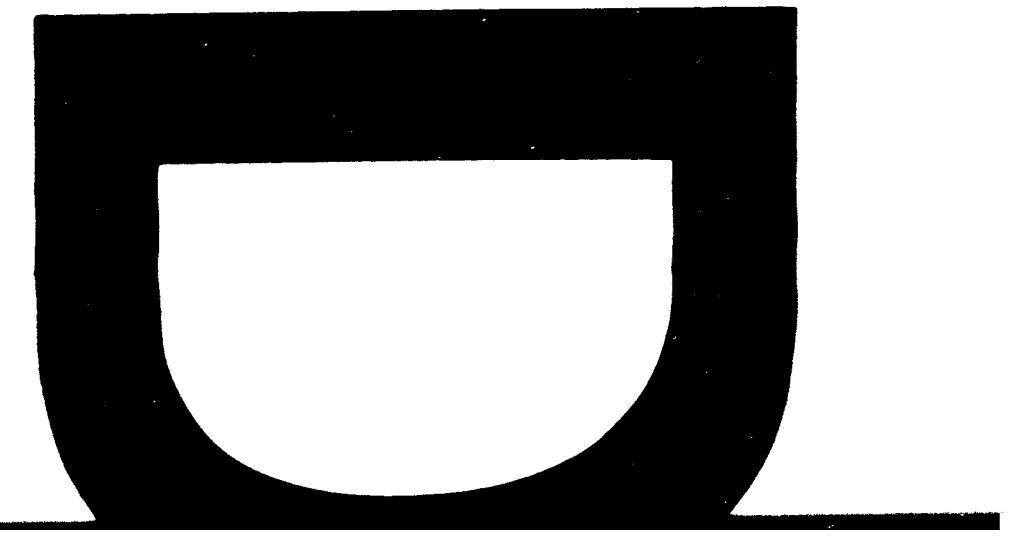


